\title{
Limits to molecular matched-pair analysis: the experimental uncertainty case
}

\author{
Christian Kramer*, Klaus Liedl \\ From 9th German Conference on Chemoinformatics \\ Fulda, Germany. 10-12 November 2013
}

Matched-Molecular Pair (MMP) analysis has recently emerged as a data analysis technique in medicinal chemistry. It quickly gained scientific momentum because it tackles key questions in lead optimization. In contrast to classical global QSAR models that attempt to predict the absolute numbers of ADME (absorption, distribution, metabolism, excretion) and toxicological properties, MMP analyses predict the difference in (bio-) chemical properties that can be expected due to small chemical modifications to lead structures, with a much smaller and well-controlled error than global QSAR models.

The power of MMP analysis depends on the number of previously documented similar molecular transformations, whereas the definition of chemical similarity plays a key role: the more generous the definition of similarity of the anchoring region, the more examples are available. The more strict the definition of similarity, the lower the variability and thus the clearer the effect on ADME-Tox parameters, but also the less data pairs will be available [1].

The (bio-) chemical effect and the significance of the results depends on the experimental uncertainty (=noise) in the data. There is a clear mathematical association between the noise level and the minimum activity difference necessary for statistical significance. Here we demonstrate how the experimental uncertainty and variability [2,3] affect Matched Molecular Pair Analysis. It can be shown that for small sample sizes (Context-specific MMPs), the activity differences have to be very large in order to be statistically significant. A full equation for the estimation of minimum significant activity difference, depending on the number of samples, standard deviation of the measurements and the true variance of the biochemical effect is developed. The influence of consistency

\footnotetext{
* Correspondence: Christian.Kramer@uibk.ac.at

Department of General, Inorganic and Theoretical Chemistry, University of Innsbruck, 6020 Innsbruck, Austria
}

(C) 2014 Kramer and Liedl; licensee Chemistry Central Ltd. This is an Open Access article distributed under the terms of the Creative Commons Attribution License (http://creativecommons.org/licenses/by/2.0), which permits unrestricted use, distribution, and reproduction in any medium, provided the original work is properly cited. The Creative Commons Public Domain Dedication waiver (http://creativecommons.org/publicdomain/zero/1.0/) applies to the data made available in this article, unless otherwise stated. of assay setups can directly be quantified via the variability and practical consequences for MMP analysis will be presented.

Published: 11 March 2014

\section{References}

1. Papadatos G, Alkarouri M, Gillet VJ, Willett P, Kadirkamanathan V, Luscombe CN, Bravi G, Richmond NJ, Pickett SD, Hussain J, Pritchard JM, Molecular Pairs: Inclusion of Contextual Information for Enhanced Prediction of hERG Inhibition, Solubility, and Lipophilicity. J Chem Inf Model 2010, 50:1872-1886.

2. Kramer C, Kalliokoski T, Gedeck P, Vulpetti A: The Experimental Uncertainty of Heterogeneous public Ki Data. J Med Chem 2012, 55:5165-5173.

3. Kalliokoski T, Kramer C, Vulpetti A, Gedeck P: Comparability of Mixed IC50 Data - A Statistical Analysis. PLOS ONE 2013, 8(4):e61007.

doi:10.1186/1758-2946-6-S1-O6

Cite this article as: Kramer and Liedl: Limits to molecular matched-pair analysis: the experimental uncertainty case. Journal of Cheminformatics 2014 6(Suppl 1):06. Cooper AWJ, Macdonald SJF: Lead Optimization Using Matched

\section{Publish with ChemistryCentral and every scientist can read your work free of charge \\ "Open access provides opportunities to our colleagues in other parts of the globe, by allowing anyone to view the content free of charge." W. Jeffery Hurst, The Hershey Company. \\ - available free of charge to the entire scientific community - peer reviewed and published immediately upon acceptance \\ - cited in PubMed and archived on PubMed Central \\ - yours - you keep the copyright \\ Submit your manuscript here: \\ Submit your manuscript here:
http://www.chemistrycentral.com/manuscript/}

